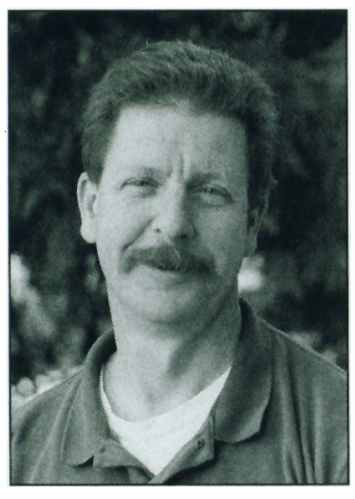

\title{
UC research can foster science-based land-use planning
}

\author{
Rick Standiford \\ Associate Dean of Forestry \\ UC Berkeley College of Natural Resources
}

$\mathrm{C}$ alifornia is home to one of the most rapidly growing human populations in the world. The state's population has grown from less than 100,000 people in 1850, to over 31 million people today (an average annual rate of growth of $3.4 \%$ ) and is projected to reach 52 million people by 2030 (see California Agriculture, January-February 2000).

The extent and condition of California's oak woodlands, or hardwood rangelands, is a sensitive gauge of the impacts of this population growth on agriculture and natural resources. Since European settlement of California, oak woodlands have been managed primarily for livestock production. These areas have taken on a new importance because of the recognition that they have the richest species abundance of any habitat in the state, with over 300 vertebrate species, 5,000 invertebrate species, and 2,000 plant species found on oak woodlands. Oak woodlands also provide water quantity and quality, outdoor recreation and aesthetics. Over $80 \%$ are in private ownership.

A survey of oak woodland owners by Lynn Huntsinger and Louise Fortmann of Berkeley's College of Natural Resources showed that the majority of all owners of California's oak woodlands now live less than 5 miles from a subdivision. Of parcels surveyed, $5 \%$ were subdivided for residential development in just 7 years, between 1985 and 1992. The urban interface with oak woodlands, once confined to the major population centers of the San Francisco Bay, Sacramento, and the Los Angeles basin, now extends throughout the state. The impacts include fragmentation of both native habitat and agricultural enterprise, increased invasion by exotics, and degradation of water quality. Despite these effects, two-thirds of all hardwood rangelands are still grazed by domestic livestock, demonstrating that it is possible for agriculture (ranching) and natural resources (oak woodlands) to jointly produce valuable commodities, such as livestock and biodiversity.

The Integrated Hardwood Range Management Program (IHRMP) started in the mid-1980s to address conservation issues affecting the state's 10 million acres of oak woodlands. There was a great deal of uncertainty as UC entered into this program of research and education. Some members of the environmental community felt that UC's strong traditional ties with commercial agriculture made it inappropriate for the University to assume a strong conservation stance. Some in the agricultural community felt that the program might jeopardize the successful working relationships that had made California agriculture highly productive and economically efficient. Today, most in both communities believe these concerns were unfounded.
The IHRMP has funded over 70 research studies over the past 14 years, resulting in over 300 new scientific articles. These form the basis for an aggressive educational effort directed at landowners, resource management professionals, policy-makers, and land-use planners. Surveys implemented to evaluate the program's effectiveness show that individuals who participated in IHRMP educational programs were more likely to carry out oak-enhancing management activities than nonparticipants. At the same time, IHRMP staff, in partnership with county CE advisors, worked at the local level to assist in the development of science-based local policies to conserve oak woodlands. Of the 41 counties with significant hardwood rangeland acreage, 31 have adopted some form of local conservation policy, and another 5 are in the process of developing local policies. The IHRMP has provided input into these policies, which include a mix of voluntary management guidelines, modifications of the county general plans, and the development of local ordinances.

A decade ago, controversy surrounded the use of oak woodlands for grazing. The environmental impacts included reduction in oak populations, loss of habitat value, and impairment of watersheds. UC played a major role in extending science-based information to livestock producers, resulting in widespread changes in ranching practices which mitigated these impacts. Currently, controversy surrounds the conversion of oak woodlands to intensive agricultural production of wine grapes. There are close analogies between this situation and IHRMP's historical work with livestock producers. We are embarking on a similar venture with grape producers. This issue of California Agriculture features recent research on the North Coast by IHRMP Specialist Adina Merenlender and her colleagues, which incorporates ecological, agronomic and economic factors in a spatially oriented land use model. This research allows local producers, policy-makers and interest groups to evaluate current trends in conversions, and to assess the impact of alternative public policies. The goal is to maintain economically viable agricultural enterprises and healthy oak woodland ecosystems.

California faces a future with more people creating more demands on its fixed land base. UC research and extension programs must continue to deliver science-based education to land managers and policy-makers, ensuring that both the rich natural resources of the state and its strong agricultural traditions are maintained. 